\title{
Oil Pollution and Bio-Diversity Conservation in Nigeria: An Assessment of Legal Framework
}

\author{
Adesina Temitayo Bello, Joseph Amadi \\ Department of Private and Commercial Law, School of Law and Security Studies, Babcock University, Iperu-Remo, Ogun State, \\ Nigeria \\ Email: tayobellous@gmail.com
}

How to cite this paper: Bello, A. T., \& Amadi, J. (2019). Oil Pollution and Bio-Diversity Conservation in Nigeria: An Assessment of Legal Framework. Journal of Geoscience and Environment Protection, 7, 354-371.

https://doi.org/10.4236/gep.2019.78024

Received: June 24, 2019

Accepted: August 26, 2019

Published: August 29, 2019

Copyright (C) 2019 by author(s) and Scientific Research Publishing Inc. This work is licensed under the Creative Commons Attribution International License (CC BY 4.0).

http://creativecommons.org/licenses/by/4.0/

\begin{abstract}
Oil pollution distorts aquatic life which not only destroys the source of livelihood of fishers, but also causes a shortage of supply of seafood. It destroys the fertile soil, which makes it difficult for the farmer to farm as a means of livelihood, and the supply of agricultural produce is reduced as a result of poor crop yields. This article deals with the effects of oil pollution on biological diversity in Nigeria. It espouses the legal regime of oil pollution and biological diversity. The article highlights threatened components of the country's biological diversity and the measures taken by the government to control and checks the activities of oil companies in a bid to ensure that they abide by best practices for the conservation of the country's biological diversity. This article recommended that there needs to be a collective effort of the government, Petroleum Companies and host communities to ensure that Nigeria's Bio-diversities is conserved. The article established that Bio-diversity is the true essence of natural life; however, oil pollution can cause the total destruction of this natural life, hence, the need for the conservation of our bio-diversity, for the protection of the environment and human existence.
\end{abstract}

\section{Keywords}

Oil Pollution, Biological Diversity Conservation

\section{Introduction}

Nigeria is highly endowed with a lot of natural resources. Nigeria occupies a total area of $923,768 \mathrm{~km}^{2}$, which basically consists of $910,768 \mathrm{~km}^{2}$ land and 13,000 $\mathrm{km}^{2}$ water, with a population of over 160 million. The principal natural resources of Nigeria include fossil fuels (coal, petroleum, lignite, natural gas), metallic minerals (columbite, gold, tin, led, iron, zinc), radioactive minerals (thu- 
lium, monazite, uranium), non-metallic minerals (marble, feldspar, limestone, clay, gravel, shale, etc.) and arable land (The United Nations Agenda 21, 2012). Nigeria is the largest oil producer in Africa, and the sixth largest in the Organization of Petroleum Exporting Countries (OPEC). As at 2019, Nigeria had a maximum crude oil production capacity of 2.53 million barrels per day, with an approximate gas production of 1681.66 billion scf: 1371.5 billion scf was associated gas and the rest 310.16 billion was non-associated gas. However, it is rather unfortunate that all these enormous resources have not in any way transformed Nigeria to one of the most prosperous countries in the African continent. This is a result of corruption, negligence and mismanagement of wealth, which has left many Nigerians impoverished. There is an annual per capita gross national product of $\$ 379$ (CEIC, 2018). The Niger Delta region, which is the main seat of oil and gas production in Nigeria, is suffering from the destructive effects of oil and gas exploration and production in terms of enormous oil pollution, biological diversity degradation and extinction.

To this effect, a cursory look into the instances of oil pollution and the adverse effects on the biological diversity of the environment has been critically examined in conjunction with the legal framework, machinery and mechanisms that can be effectively employed to salvage the precarious situation. This will ensure that the biological diversity of the country is not only conserved, but mankind has a better chance of good living. To correct this situation it is recommended that oil exploration and production companies should sign contracts with the government to assure them of proper cleaning up of the environment where the exploration and production are done. Also there should be enforcement bodies that will scrutinize the oil production companies and ensure that they comply with all agreements entered into with the government and defaulters should be properly punished.

This work thus considers the following:

1) The Concept of Oil Pollution in Nigeria: By appraising various legislative definitions, considering areas such as Oil spillage, Gas Flaring.

2) The Concept of Bio-Diversity: noting the various aspects through which Bio-Diversity affects the country i.e. the Biological, Social and Economic Implications.

3) The Legal and Institutional Framework on Oil Pollution including the Department of Petroleum Resources.

4) Government's effort in combating oil pollution in Nigeria: This has been done by stating the various ways by which the government has tried to fight oil pollution in Nigeria, most especially through enactment of laws to punish offenders.

\section{Concept of Oil Pollution in Nigeria}

The Federal Environmental Protection Agency Act defines "pollution" as "Man-made or man aided alterations of chemical, physical or Biological quality 
of the environment to the extent that is detrimental to that environment or beyond acceptable limits." ${ }^{\text {A }}$ According to the United Nations Convention on Law of the Sea, pollution is defined as the

"introduction by man, directly or indirectly of substances or energy into the marine environment, coastal zones and related inland waters resulting in such deleterious effects as harm to living resources, hazards to human health, hindrance to marine activities, including fishing, impairments of quality use of sea-water and reduction of amenities".

Oil pollution occurs in two ways: oil spillage and gas flaring. However, for better understanding of the concept of oil pollution both forms of pollution will be examined.

\section{OIL SPILLAGE ON LAND}

Oil pollution has the probability of infiltrating land. Research shows however that over time land has been polluted by oil condiments. According to Wild, mining, oil exploration and production and other downstream operations result in liquid spills and leakages of hydrocarbon solvents and chemicals and they all contribute in the contamination of land. Oil exploration and exploitation activities damage the soil and prevent crop growth for varying period of time (Wild, 1996). These damaging effects are due to suffocation and toxicity of the crude oil. A typical illustration is seen in the Shell-Bp Bomu II blowout of 1970 and Elf Obagi II blowout of 1972 seriously affected agricultural land, brackish water and mangrove swamps in the Niger-Delta area. Nevertheless, Osisanya is of the view that a spill will contaminate the soil with which it comes in contact making it unfertile and turning it into a reservoir from which volatile compounds can be emitted (Osisanya, 2003). Due to the porosity of the soil, the spill/leakage can flow as a result of gravity and capillary action (upward movement of liquid in the soil) to contaminate ground and surface water.

The case of Shell Petroleum Development Co. Ltd v F.B. Farar \& Ors concerning an oil facility blow out which occurred in July 1970 from a well owned and operated by the appellants offers a graphic example of the impact of oil spillage on land contamination. In this case, the blow out lasted for several weeks during which time, crude hydrocarbons, sulphur and effluent toxic substances were emitted in dense fountains ${ }^{4}$. The emissions formed a thick layer over the surface of the adjoining land, destroying farmlands, crops and economic trees and natural vegetation of the impacted areas with the resultant desertification of the impacted areas of about 607 hectares belonging to various families ${ }^{5}$.

The Guardian Newspaper reports that the National Oil Spill Detection and Response Agency of Nigeria state that there have been a total of 3203 cases of oil spills in the Niger Delta region alone in the last four years (Nnimo, 2010). On

${ }^{1}$ FEPA Cap.F10 LFN 2002. Section 41.

${ }^{2}$ UNCLOS III, 1982. Art. 1(4).

${ }^{3}$ (1995) 3 NWLR. (Pt. 382) 148, Shell Petroleum Dev. Co. v Maxon (2001) 9 NWLR (Pt. 719) 541.

${ }^{4}$ Ibid.

${ }^{5}$ Ibid. 
February 20, 1991 the Punch Newspaper reported a total of 2796 oil spill incidences recorded between the periods of 1976-1990 leading to 2,105,393 barrels of oil spilled. The United Nations Development Programme (UNDP), in 2006, disclosed that between the periods of 1976-2001, 3 million barrels of oil were lost in 6817 oil spill incidences of which over $70 \%$ of the spilt oil was not recovered (UNDP, 2006). The figure below gives an account of Spill Incidence from 2010 to 2014 (Table 1, Figure 1, Figure 2):

Table 1. Spill incidence summary from 2010 to 2014. Source: Department of Petroleum Resources 2014 Annual Statistical Bulletin available at $\langle\underline{h t t p: / / w w w . d p r . g o v . n g / i n d e x / ~}>$ Accessed 5/06/2019.

\begin{tabular}{ccc}
\hline Year & Number of Spills & Quantity Spilled (Barrels) \\
\hline 2010 & 537 & $17,658.10$ \\
2011 & 673 & $66,906.84$ \\
2012 & 844 & $17,526.37$ \\
2013 & 522 & 4066.20 \\
2014 & 1087 & $10,302.16$ \\
\hline
\end{tabular}

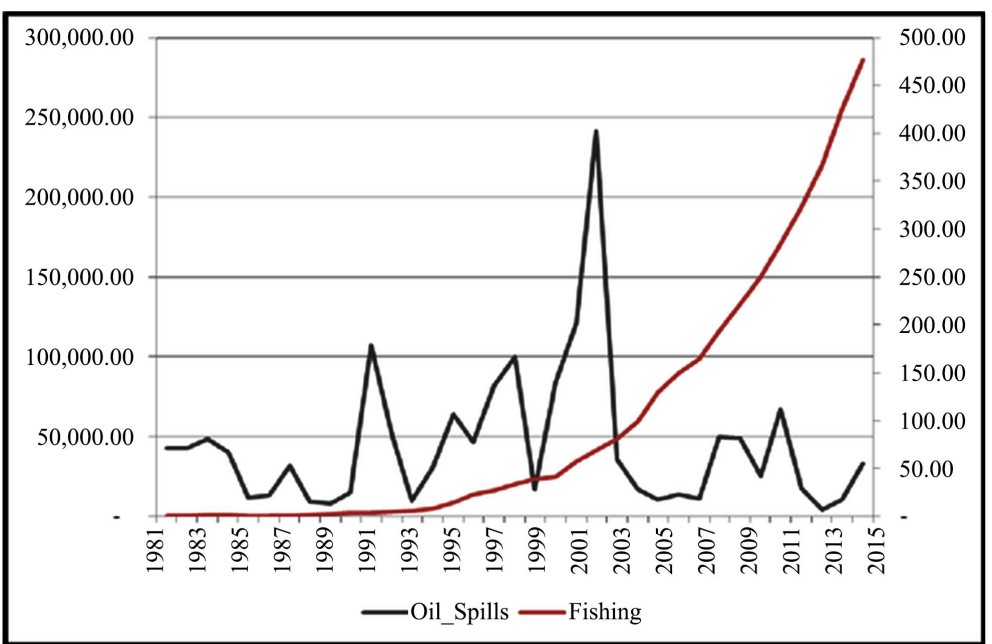

Source: Department of Petroleum Resources (2016)

Figure 1. The effect of oil spills on fishery in the Niger Delta, the more the spills the more the death of the fishes. SOURCE (Osuagwu \& Olaifa, 2018): https://journals.plos.org/plosone/article/figure?id=10.1371/journal.pone.02 05114.g003: Accessed July 8, 2019.

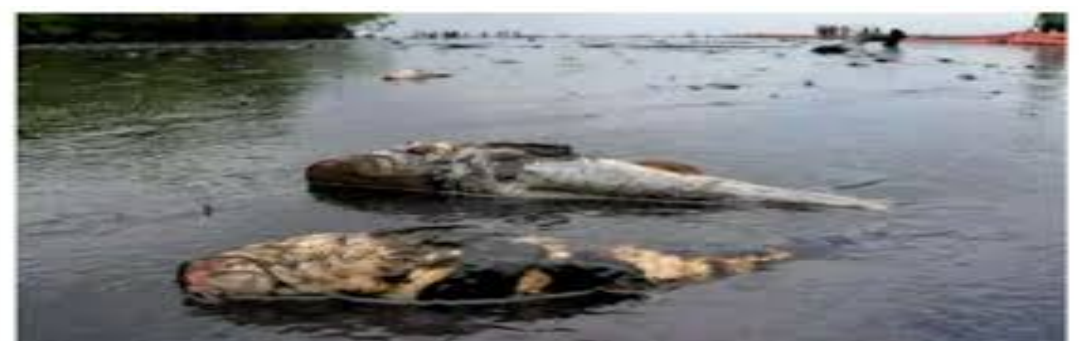

Figure 2. Shows the deadly effect of oil spillage in Niger Delta, where fishes and other animals were affected. SOURCE: UNEP Report (2011). 
Other causes of oil spillage are pipelines failure which can take the form of material defect, pipeline corrosion, ground erosion, and sabotage, among others. Nonetheless, the Department of Petroleum Resources contends that $88 \%$ of this oil spill incidences are traceable to equipment failure (UNEP, 2011). Other obvious causes of oil spills in Niger delta are vandalism, oil blowouts from the flow stations, accidental and deliberate releases and oil tankers at sea (Nwilo \& Badejo, 2005).

\section{GAS FLARING}

Gas flaring is the burning off of the natural gas associated with the crude oil during extraction in places where there is no capacity or infrastructure to trap and make use of the gas. More so, it is a process by which unusable or excess natural gas is released by a pressure valve and burned-releasing tonnes of carbon dioxide into the atmosphere (Sunmoni, 2012). A Gas flare, also known as "flare stack" is a combustion tool employed at industrial plants and gas production sites such offshore gas and rigs, gas wells, oil wells and landfills. Nigeria flares 17.2 billion cubic metres of natural gas per year in conjunction with the exploration of crude oil in the Niger Delta (Michiko, 2004). The effects of gas flaring on the Nigerian environment cannot be overemphasized as it affects both flora and fauna components of the fragile ecosystem. For instance, birds exposed to hydrocarbons concentration can have an impaired ability to fly, preventing it from foraging. Irritation of the digestive tract, altered liver function and kidney damage, metabolic imbalance, hormonal imbalance, including changes in their luteinisation of protein, are but a few of the effects of exposure to hydrocarbon concentrations on birds.

More gas is flared in Nigeria than anywhere else in the world. These flares have contributed more greenhouse gases than all of sub-Saharan Africa combined. The flares contain toxins that affect the health and livelihood of local communities, exposing Niger Delta residents to an increased risk of premature deaths, child respiratory illnesses, asthma and cancer (Asume, 2005). Acid rain is another problem within the Niger Delta region caused by gas flaring which has caused loss in Bio-diversity, with forest and economic crops being destroyed. It is opined that the dominance of grasses and shrubs in some parts of the region is indication of loss of natural forest, this may be due to acid rain but other factors may be the cause such as exploitation and exploration of oil companies (Uyigue \& Agho, 2007). Furthermore, the concentration of acid in rain water appears to be higher in the Niger Delta region and decreases further away from the region (Uyigue \& Agho, 2007). In addition, the heat generated from gas flaring is seriously alarming as this heat kills vegetation around flaring area, destroys mangrove swamps and salt marshes, suppresses the growth and flowering of some plants, induces soil degradation and diminishes agricultural productivity (Mba, 2000). Apart from its adverse effects on agricultural productivity, humans are also highly affected due to the toxicity of flared gas which is capable of causing respiratory illness, leading to kidney disease, neurological disease and potential death (Ndubuisi \& Asia, 2007). The cumulative environmental impact of gas 
flaring result in contaminant build up on land, shallow ground water, greenhouse effect and general global warming and have also caused high concentration of acid rain within the region (Uyigue \& Ogbeibu, 2007) (Figure 3).

\section{Concept of Bio-Diversity}

The term Bio-diversity as the variation among living organisms, which encompasses species diversity (the number of different species), genetic diversity (gene pool variety within species) and ecosystem diversity (the variety of interactions among living things in natural communities) (Okiwelu \& Anyawu, 2003). This term is also applied to describe the number, variety and variability of living organisms. However, science has revealed that plants, fishes, birds, animals and even man all make up the Bio-diversity of an environment. On the other hand, the term Conservation is the sustainable exploitation of natural resources (land, forestry, wildlife and marine resources) for optimal and maximum yields of the present generations while preserving its potential to meet the needs and aspirations of future generations (IUCN/UNEP/WWF, World Conservation Strategy: Living Source Conservation for Sustainable Development, 1980). Nonetheless, the key purposes of conservation are to maintain essential ecological processes and life support system, preservation of genetic resources and sustainable utilization of species and ecosystems (IUCN/UNEP/WWF, World Conservation Strategy: Living Source Conservation for Sustainable Development, 1980). This definition is clearly reflected in the objectives of the Convention on Bio-diversity, which are the conservation of Bio-diversity, the sustainable use of its components, the fair and equitable sharing of the benefits arising through the utilization of genetic resources (United Nations, 1992).

Article 2 of the Convention on Bio-diversity, defines Bio-diversity as,

"the variability among living organisms from all sources and includes diversity between species, within species and of eco systems."

From this definition it is apparent that Bio-diversity does not only encompass species diversity, but also includes genetic and ecosystem diversity (Amokaye, 2004). Species diversity refers to the diversity of species with given populations within which gene flows occur under natural conditions (Amokaye, 2004). Genetic diversity on the other hand means the range of genetic material found in the world's organisms, upon which depends the functioning of many of the above processes and life-support systems, the breeding programmes necessary for the protection and improvement of cultivated plants, domesticated animals and micro-organisms, as well as much scientific and medical advance, technical innovation and the security of many industries that use living resources. Ecosystem diversity relates to the variety of habitats, biotic communities and ecological processes in the biosphere as well as the diversity within ecosystems.

Soule (Soules, 1991), opined that there are five levels in the Bio-diversity hierarchy: 


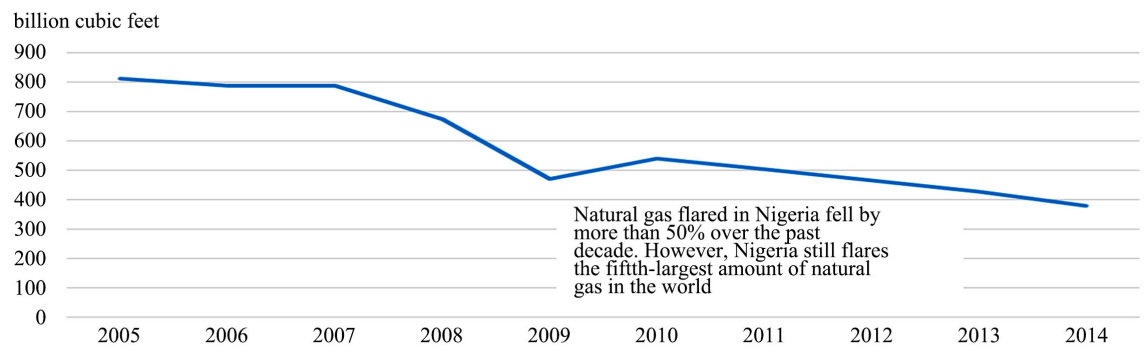

Figure 3. Natural gas flared in Nigeria. Source: U.S. Energy Information Administration, OPEC Annual Statistical Bulletin 2015.

1) Whole system such as landscapes or ecosystems,

2) Assemblages such as associations or communities,

3) Species;

4) Populations,

5) Genes.

From these elements, the diversity of ecosystems might be regarded as the concept commanding the highest level of importance, since all living organisms exist and function not in isolation but as part of a wider environment, occupying a particular niche within their appropriate ecosystems, and it is through the preservation of entire ecosystems that diversity can most effectively be secured (McNeely et al., 1996).

\section{Nigeria's Bio-Diversity Endowment}

Nigeria is very rich in Bio-diversity. The country is endowed with a variety of plant and animal species. There are about 7895 plant species identified in 338 families and 2215 genera. There are 22,000 vertebrates and invertebrates species. These species include about 20,000 insects, about 1000 birds, about 1000 fishes, 247 mammals and 123 reptiles. About 1489 species of microorganisms have also been identified. All of these animal and plant species occur in different numbers within the country's vegetation that range from the mangrove along the coast in the south to the Sahel in the north. Besides, there are bamboos and grasses which are useful for making a variety of products, especially in local cottage industries. Furthermore, in the Niger Delta are found various and extensive forests which harbor a rich diversity of wildlife, including mammals, reptiles, birds, insects and other invertebrates - a good number of species being endemic to the region. The water bodies hold a wide variety of aquatic life, including shellfish and crustaceans (Niger Delta Environmental Survey, 1997).

\section{Effects of Oil Pollution on Bio-Diversity}

Crude oil has benefited Nigeria to a great extent; however, it is not incontrovertible to assert that oil pollution has adverse effects on Nigeria's Bio-diversity. These effects are categorised into three as follows:

Biological impact: loss of Bio-diversity and destruction of habitats, largely due to top soil degradation is a main adverse effect of oil pollution. The process 
of photosynthesis is also impaired as a result of the introduction of phytotoxins into the environment wherever oil spills occur.

Economic impacts:

The economic impacts can be categorized into four (4) groups as follows:

1) Nutritional Deficiency and Food Shortages: Oil pollution results in the destruction of the Niger Delta traditional local economic support systems of fishing and farming. The combination of the effects of oil spillage and acid rain resulting from gas flaring has been soil degradation which affects crop yield and harvest (Pyagbara, 2007). Fishes are driven away from in-shore or shallow waters into deep-sea as a result of pollution caused through gas flaring.

2) Destruction of Traditional Means of Livelihood: Oil pollution renders the agricultural sector, which is one of the largest employer of labour in Nigeria, especially in the Niger-Delta region, unprofitable, leaving youths and women jobless since their local economic support system of fishing and farming is no longer sustainable.

3) Migration and the Rise of Environmental Refugees: The condition of the Ogoni people is a remarkable example of migration from communities and increase in environmental refugees. The Ogoni people lived in closely knitted communities with a subsistent economy providing them with their basic needs. As a result establishment of oil production companies, most of the Ogoni dwellers have migrated.

4) Militancy: The effects of oil pollution on the people of the Niger-Delta and the failure of the Federal Government to intervene in their situation and bring sustainable development to the people of the Niger-Delta led to the initiation of militancy activities in the region.

5) Health Implications: Basically, oil pollution gives rise to the occurrence of certain ailments in areas that have suffered from oil pollution in Nigeria. This is often as a result of inhalation of contaminated air, intake of contaminated food from areas that have suffered oil pollution, and also as a result of the consumption of contaminated water.

\section{Legal Framework on the Environment}

Several steps have been taken by the government of Nigeria in the area of control and mitigation of oil pollution and the conservation of Bio-diversity using the instrumentality of laws and policies. There are also regional and international instruments in place for the mitigation of oil pollution and the conservation of Bio-diversity considered in course of this article.

INSTITUTIONS CREATED BY LAW FOR THE CONTROL AND MITIGATION OF OIL POLLUTION

Department of Petroleum Resources (DPR): The DPR is the regulatory arm of the oil and gas industry in Nigeria. Its mission statement is-

"To serve as the watchdog over the development of our nation's oil and gas resources, by employing modern tools and techniques to direct, influence and 
achieve the optimum exploitation, conversion and utilization of petroleum and its derivatives for the maximum benefit of Nigerians while ensuring minimal damage to the environment." (Akinjide-Balogun, 2001)

The DPR has the power to issue environmental guidelines for the petroleum industry in Nigeria. This power derives from the following:

- Section 9(1)(f) and 12(1) of the Petroleum Act where under certain powers of the Minister may be delegated to the Director of DPR.

- Inference from the provisions of Section 10(2) to Section 11 of the Nigerian National Petroleum Corporation Act (Cap 320) which charges DPR's predecessor with supervisory and regulatory functions over the petroleum industry.

- Section 23 of the FEPA Act which acknowledges DPR as the principal authority charged with the responsibility for the "removal of oil related pollution discharged into the Nigerian environment".

The Department of Petroleum Resources (DPR) administers oil and gas laws in Nigeria as well as legislative instruments that are made to ensure that oil companies carry out petroleum exploration and production in line with best practices for sustainable development.

National Oil Spillage Detection and Response Agency (NOSDREA): NOSDREA was established in 2004 as an initiative of the Ministry of Environment. Its main aim is to administer the National Oil Spill Contingency Plan (NOSCP) in compliance with the International Convention on Oil Pollution Preparedness, Response and Cooperation, of which Nigeria is a signatory.

NOSDRA seeks to achieve zero tolerance for oil spill incidences in Nigeria, while advocating for the restoration and preservation of the environment by ensuring good practices in oil exploration, storage and production, with the aim of achieving sustainable development.

1999 CONSTITUTION OF THE FEDERAL REPUBLIC OF NIGERIA (AS AMENDED): Section 20 of the Constitution makes it a fundamental objective of the Nigerian State to improve and protect the air, land, water, forest and wildlife of Nigeria. Section 12 provides that international treaties (including environmental treaties) ratified by the National Assembly be implemented as law in $\mathrm{Ni}$ geria. Furthermore, Section 33 and Section 34 of the Constitution guarantees the fundamental human rights to life and human dignity respectively and they are inextricably linked with the protection and preservation of the environment from harm, degradation or destruction.

NATIONAL ENVIRONMENTAL STANDARDS AND REGULATION ENFORCEMENT AGENCY (NESREA) ACT 2007: NESREA is an agency administered by the Ministry of Environment. The NESREA Act of 2007 replaced the FEPA Act. It is the embodiment of laws and regulations focused on the protection and sustainable development of the environment and its natural resources. Section 7 provides authority to ensure compliance with environmental laws, local and international, on environmental sanitation and pollution pre- 
vention and control through monetary and regulatory measures. Section 27 prohibits, without lawful authority, the discharge of hazardous substances into the environment.

HARMFUL WASTE (SPECIAL CRIMINAL PROVISIONS) ACT CAP H1, LFN 2004: The Harmful Waste Act prohibits, without lawful authority, the carrying, dumping or deposition of harmful waste in the air, land or waters of Nigeria with the purpose of enhancing biodiversity. Section 6 provides for a punishment for life imprisonment for offenders as well as the forfeiture of land or anything used to commit the offence. Section 7 makes provisions for the punishment accordingly, of any conniving, consenting or negligent officer where the offence is committed by a company.

\section{Legal Framework on Bio-Diversity}

Hereunder, the legal framework on Bio-diversity conservation will be considered under these three headings-Municipal, Regional and International.

\section{Municipal:}

The following are some of the laws and regulations put in place by the Nigerian government for environmental protection, planning, pollution prevention and control, and the conservation of Nigeria's Bio-diversity.

THE ENDANGERED SPECIES (CONTROL OF INTERNATIONAL TRADE AND TRAFFIC) ACT, 1985. CAP E9, LFN 2004: This Act focuses on the protection and management of Nigeria's wildlife and some of their species in danger of extinction due to overexploitation. The Act was enacted to fulfill the obligation assumed under the Convention on International Trade in Endangered Species.

SEA FISHERIES ACT, CAP S4, LFN 2004: The Sea Fisheries Act makes it illegal to take or harm fishes within Nigerian waters by use of explosives, poisonous or noxious substances. Section 1 prohibits any unlicensed operation of motor fishing boats within Nigerian waters. Section 10 makes destruction of fishes punishable with a fine of N50,000 or an imprisonment term of two years. Section 14(2) provides authority to make for the protection and conservation of sea fishes.

The goal of the country Nigeria is to converse and sustain the use of Biodiversity. This is because the provision of Article 6 of Sea Fisheries Act is very similar to that of Article 10(a) of the Convention on Biological Diversity. Both provide for the incorporation of biodiversity conservation and sustainable use into the national programmes of party countries. ${ }^{6}$

INLAND FISHERIES ACT, CAP I10, LFN 2004: This Act focuses on the protection of the water habitat and its species. Section 1 prohibits unlicensed operations of motor fishing boats within the inland waters of Nigeria. Section 6 prohibits the taking or destruction of fish by harmful means. This offence is punishable with a fine of 3000 or an imprisonment term of 2 years or both.

${ }^{6}$ See the implementation of article 6 of the Convention on Biological Diversity. 
The Inland Fisheries Decree is enacted for the promotion of the conservation of the fish resources and the sustainable use of their components. ${ }^{7}$ It provides for sanctions for noncompliance.

WATER RESOURCES ACT, CAP W2, LFN 2004: The Water Resources Act is targeted at developing and improving the quantity and quality of water resources. Sections 5 and 6 provide authority to make pollution prevention plans and regulations for the protection of fisheries, flora and fauna. Section 18 makes offenders liable, under this Act, to be punished with a fine not exceeding 2000 or an imprisonment term of six months. He would also pay an additional fine of 100 for everyday the fine continues.

THE FEDERAL NATIONAL PARKS ACT, CAP N65, LFN 2004: The National Parks Act is concerned with the establishment of protected areas used for resource conservation, water catchments protection, wildlife conservation and maintenance of the national eco-system balance.

\section{Regional and International:}

Some of the Regional and International legal instruments for the conservation of Bio-diversity include:

1) African Convention on the Conservation of Nature and Natural Resources 1968.

2) Convention on Bio-diversity (Rio Conference) 1992.

AFRICAN CONVENTION ON CONSERVATION OF NATURE AND NATURAL RESOURCES 1968: The fundamental principle of the Convention is the obligation it imposes on contracting states to "adopt the measures necessary to ensure conservation, utilization and development of soil, water, flora and fauna resources in accordance with the scientific principles and with due regard to the best interest of African people"s.

CONVENTION ON BIO-DIVERSITY 1992: The United Nations Convention on Bio-diversity (CBD) was signed at Rio de Janeiro in 1992 by 157 State Parties after the Intergovernmental Negotiating Committee for a Convention on Bio-diversity, a committee set up by the United Nations Environmental Programme, adopted the final draft of the convention on 22 May, 1992. The Convention represents the commitment of nations of the world to conserve Bio-diversity, to ensure biological sustainability and to share, equitably, the benefits arising from the use of genetic resources. The Convention contains $42 \mathrm{Ar}-$ ticles and is a legal framework to promote the adoption of all measures aimed at ensuring; 1) conservation of Bio-diversity, 2) sustainable use of its components, and 3) the fair and equitable sharing of benefits arising from the use of genetic resources. ${ }^{9}$

INTERNATIONAL CONVENTIONS RELATING TO OIL POLLUTION

Records and data show that the highest degree of pollution comes from off-shore sources and that coastal countries not surprisingly are its greatest vic${ }^{7}$ Inland Fisheries Decree No 1081992 CAP I10 LFN 2004.

${ }^{8}$ African Convention on Conservation of Nature and Natural Resources 1968, Art. 11.

${ }^{9}$ United Nations, 1992. Art. 1. 
tims (Weis, 2015). Attempts have been made through international conventions to address this unsatisfactory situation; thus the main source of the law regulating pollution from off-shore causes can be traced to international treaties and conventions. The following are some of these international conventions.

The United Nations Convention on Law of the Sea 1982: This convention was adopted in 1958 but updated in 1982. It is generally regarded as the basic law on matters relating to the pollution of the sea. Pollution of the marine environment is defined to mean "the introduction by man, directly or indirectly, of substances or energy into the marine environment, including estuaries, which results or is likely to result in such deleterious effects as harm to living resources and marine life, hazards to human health, hindrance to marine activities, including fishing and other legitimate uses of the sea, impairment or quality for use of sea water and reduction of amenities." ${ }^{10}$ Nigeria is a party to the convention, signed December 10, 1982, ratified August 14, 1986. The agreement was deposited on October 25, 1994 and was subsequently ratified again on July 28 , 1995. Nigeria has always complied with the convention in order to protect the environment and enhance biodiversity.

\section{Government Efforts in Combating Oil Pollution in Nigeria}

\subsection{Statutory Enactments}

Associated Gas Re-injection Act 1979: Oil companies were mandated to cease gas flaring. Flaring could only be done for operational reasons with the permission of the Petroleum Minister. ${ }^{11}$

Environmental Impact Assessment Act, 1992: This Act makes it mandatory for an environmental impact assessment (EIA) study of a project (which is likely to significantly impact the environment), to be prepared at the early stage of the project often before the project is undertaken. ${ }^{12}$ The EIA is to be directed to the Federal Environmental Protection Agency for approval (Etikerentse, 2004). Any project whose EIA is disapproved by the agency cannot be undertaken ${ }^{13}$. This will help to ensure that any oil and gas exploration and production process is properly assessed before the oil companies commence such project.

Federal Environmental Protection Agency Act 1988: This Act established the Federal Environmental protection Agency. It charges the agency with the responsibility of prescribing the criteria and standards for protecting the Nigerian environment. The law requires the agency to encourage the establishment of environmental protection agencies in States and Local government areas ${ }^{14}$. More so, it acknowledges the Department of Petroleum Resources (DPR) as having the principal responsibility for the "removal of oil related pollutants discharged into the Nigerian environment" and stipulates that the agency should cooperate with

\footnotetext{
${ }^{10}$ UNCLOS 1982, Article 1(4).

${ }^{11}$ Associated Gas re-injection Act, 1979, section 3.

${ }^{12}$ EIA Act, 1992, Section 2.

${ }^{13}$ EIA Act, 1992, Section 8.

${ }^{14}$ FEPA Act 1988, Section 24.
} 
DPR in this regard ${ }^{15}$. The agency now functions as part of the Ministry of Environment after its amendment in 1992 (Etikerentse, 2004).

Harmful Waste (Special Criminal Provisions, etc.) Act, 1988: This law came into effect on the $25^{\text {th }}$ of November, 1988. It prohibits and penalizes the carrying, dumping and importation of harmful waste on any land, territorial waters and the exclusive economic zone of Nigeria. Any breach of this provision by an individual makes him guilty of an offence and punishable to a fine as provided in Section 13 of the Act. In essence, any producer or marketer who dumps petroleum waste products on territorial waters or on land would have breached the provisions of this Act.

Oil in Navigable Waters Act 1968: This Act prohibits and penalizes, the discharge, from a ship, of crude oil, fuel oil, lubricating oil, heavy diesel oil, and any mixture of oil discharged from a ship in territorial and inland waters ${ }^{16}$. The Act's prohibitions cover not only the owners or masters of Nigerian ships and the high seas of within 80 kilometres of Nigeria's territorial waters, but also Nigerian registered vessels in such far-away places like: the Mediterranean and Adriatic Seas, the Red Sea, the Persian Gulf, the Arabian Sea, the Malagasy and Australian Seas, and many others.

Oil Pipelines Act 1956, Cap 338, LFN 1990: The Oil Pipeline Act provides in Section 14 that the holder of a pipeline licence is not permitted to construct pipelines near a public road, dam or government building to prevent pipeline destruction and oil pollution. The Act further makes it an offence for any holder of the licence to breach the provisions of this $\mathrm{Act}^{17}$. More so, the Act grants the Minister the power to make Regulations for the prevention of pollution of any land or water ${ }^{18}$.

Petroleum Act 1969 (Cap 350) LFN 1990: Under the Petroleum Act the Minister has the power to make regulations ${ }^{19}$. This enables the Minister to make regulations for the prevention of pollution of land and water by those granted the Oil Mining Lease (OML). This Act also provides punishments for illegal prospectors, explorers and miners of crude oil ${ }^{20}$. This provision will ensure that oil is not explored and exploited by those without the requisite knowledge to carry out such activities in a safe and secure way that ensures that the environment is not polluted. It should be noted that the laws are paramount but not effectively implemented.

\subsection{Guidelines and Regulations}

National Environmental Protection (Effluent Limitation) Regulations 1991: This among others is a major regulation of the government for the protec-

\footnotetext{
${ }^{15}$ FEPA Act 1988, Section 23.

${ }^{16}$ Oil in Navigable Waters Act 1968, section 3.

${ }^{17}$ Oil Pipelines Act, Section 32.

${ }^{18}$ Oil pipelines Act, Section 33(c).

${ }^{19}$ Petroleum Act 1969, Section 9.

${ }^{20}$ Petroleum Act 1969, Section 13.
} 
tion of the Nigerian environment. It sets out regulations for effluent limitation. Specifically, Regulation 1 provides that companies engaged in oil and gas exploration and production should endeavour that they limit effluent discharge to the barest acceptable limits.

National Environmental Protection (Pollution Abatement in Industries and Facilities Generating Wastes) Regulations 1991: This is one of the regulations issued by FEPA to prohibit the release of hazardous or toxic substances into the air, land or water of Nigeria's ecosystem beyond the limits approved by FEPA $^{21}$.

Oil and Gas Pipelines Regulations 1995: This regulation stipulates that the construction of pipelines shall be done in a way that causes the least disturbance to the environment ${ }^{22}$. It provides that where a pipeline passes within 100 metres of a water course, the operator shall assure DPR that adequate contingency plans have been made for protecting the environment there ${ }^{23}$. Also, the regulation provides that the holder of a pipeline licence must establish emergency plans to ensure prompt and remedial action for the protection of property and the environment ${ }^{24}$.

Petroleum (Drilling and Production) Regulations, 1969 with its amendment of 1996: The Petroleum Regulations were made pursuant to the Petroleum Act of 1969. This regulation provides that a licensee or lessee of an OPL or OML may not enter upon land within a village, town, market, and cemetery or within 20 metres of a reservoir, public road, railway or any land in actual cultivation without the prior written permission from the Petroleum Resources Minister ${ }^{25}$. The lessee is expected to comply with all applicable town and country planning laws and regulation ${ }^{26}$, especially those geared towards the prevention or mitigation of oil pollution. The lessee is also expected to adopt all practicable precautions for the prevention of pollution by oil, mud or other fluid ${ }^{27}$.

Environmental Guidelines and Standards for the Petroleum Industry in Nigeria issued by the Department of Petroleum Resources (DPR): The guideline involved here is the "Environmental Guidelines and Standards for the Petroleum Industry in Nigeria" issued by DPR in 1991 and amended in 2002. It stipulates guidelines and standards for operators in the petroleum sector to ensure that they observe best practices and ensure the protection of the environment from harm that may be caused by oil. This guideline was issued by the Department of Petroleum Resources (DPR) as a result of rising concern for adverse environmental impacts arising from oil related pollution. ${ }^{28}$ EGASPIN aims

\footnotetext{
${ }^{21}$ National Environmental Protection (Pollution Abatement in Industries and Facilities Generating Wastes) Regulations 1991, Regulation 1.

${ }^{22}$ Oil and Gas Pipelines Regulations 1995, Regulation 5(d)(ii).

${ }^{23}$ Oil and Gas Pipelines Regulations 1995, Regulation 8(b).

${ }^{24}$ Oil and Gas Pipelines Regulations 1995, Regulation 9(b)(ii).

${ }^{25}$ Petroleum (Drilling and Production) Regulations 1969, Regulation 17(b)(iii) and (iv).

${ }^{26}$ Petroleum (Drilling and Production) Regulations 1969, Regulation 18.

${ }^{27}$ Petroleum (Drilling and Production) Regulations 1969, Regulation 25.

${ }^{28}$ Paragraph 3, part 1, "Introduction”, EGASPIN 2002.
} 
to establish guidelines and standards for environmental quality control of the petroleum industry in Nigeria ${ }^{29}$ and to achieve the standardisation of environmental pollution abatement and monitoring procedures in the Nigerian oil and gas industry. ${ }^{30}$

\section{Recommendations}

Oil pollution has for so long a time perpetrated the Nigerian Bio-diversity with little or nothing being done to alleviate the menace. However, to bring a stop to the seemingly unstoppable situation which has constantly terrorised the Bio-diversity of Nigeria. The recommendations include the following:

1) A Triad-Approach in tackling the problem of oil pollution and Bio-diversity conservation in Nigeria. This means that:

* The oil companies,

* The government, and

* The host communities.

Who are stakeholders in oil exploration and exploitation should work together in mapping out measures to deal with possible oil pollution and Bio-diversity loss. Basically a joint effort from these three categories will go a long way to alleviate the issue of oil pollution. More so, Oil exploration and production companies interested in exploration and production activities in Nigeria should sign agreements with the host communities and provide guarantors up-front to cover the cost of clean-ups and possible relocation of host communities in the event of oil pollution.

2) Environmental Impact Assessment should be taken seriously. Activities of oil companies should be properly scrutinized to ensure that they carry out due diligence and abide by best practices to prevent possible oil pollution and subsequent mishap to the environment. Also, on gas flaring, the Senate passed the Gas flaring (Prohibition and Punishment) Bill 2009 (SB. 126) into law (Declan, 2016), and the Gas Flaring (Prohibition and Punishment) Bill 2016 is been considered by the Senate. Furthermore, oil companies should develop and make use of technologies that would collect these gases and utilize them for other productive purposes. Large scale gas investments should be strictly encouraged.

3) Furthermore, areas identified as having endangered species of certain plants and animals should be completely sealed from any oil exploration, exploitations and production activity. Such areas should be completely reserved or completely restricted to any form of oil exploration and production activity. More so, the Nigerian National Assembly should follow the international trend in the area of environmental protection and Bio-diversity conservation and sign, ratify and implement conventions and other international instruments and its attendant protocols to ensure that the country's Bio-diversity is conserved. In addition, Government should encourage programmes such as the Bio-diversity

${ }^{29}$ Paragraph 4 (a), part 1, “Introduction”, EGASPIN 2002.

${ }^{30}$ Paragraph 4 (c), part 1, "Introduction”, EGASPIN 2002. 
Strategy and Action Plan and Game Reserves to protect, preserve and conserve our Bio-diversity.

4) Finally, Environmental Protection and Bio-diversity Conservation should be upgraded to the status of a Fundamental Human Right. All Nigerians should, as a matter of necessity, have the right to a safe and healthy environment because where our Bio-diversity is in peril, food is in short supply, and health in great danger, and ultimately the right to life cannot be assured.

\section{Conclusion}

It was noted in this article that oil pollution affects the land, the water body or air upon which oil is spilled or gas flared. Clearly, oil pollution is traumatic to the environment, and in turn, Bio-diversity which is the true essence of natural life or nature. There can be no ecosystem without a Bio-diversity, and mankind cannot possibly exist alone without other important components of the Bio-diversity. The International Union for the Conservation of Nature and Natural Resources, discovered from the evaluation of coastal regions of eleven West African countries, discovered that Niger Delta is unprotected. All components have a symbiotic relationship and they work together in order to ensure continued existence. Several components of the country's Bio-diversity are important because they provide food, medicine, raw materials for production of other essential goods. The life of a man is indirectly threatened when there is failure to control activities that destroy bio-diversity and promote oil pollution. Hence, bio-diversity is the full essence of life, without doubt there is need to conserve Nigerian Bio-diversity.

Conclusively, this article finds that

- Oil pollution has had grave consequences on the Bio-diverse nature of Nigeria.

- Although laws exist, the laws enacted are not fully complied with in order to halt the incidence of, or mitigate the effect of oil pollution.

- Clearly, the protocols to international conventions which relate to the subject have not been ratified by the Nigerian legislature, and this would only continue as an assault on the environment and contribute to the existing poor situation of Bio-diversity conservation in Nigeria.

- Thus, genuine and deliberate preservation of the Bio-diversity can only be achieved by the parties concerned which have been outlined in the recommendations of this paper.

\section{Conflicts of Interest}

The authors declare no conflicts of interest regarding the publication of this paper.

\section{References}

African Convention on Conservation of Nature and Natural Resources 1968, Art. 11. 
Akinjide-Balogun, O. (2001). Nigeria: Legal Framework of the Nigerian Petroleum Industry.

http://www.mondaq.com/x/10726/legal+framework+of+the+nigerian+petroleum+ind $\underline{\text { ustry }}$

Amokaye, O. G. (2004). Environmental Law and Practice in Nigeria (p. 251). Lagos: University of Lagos Press.

Asume, O. (2005). Gas Flaring in Nigeria: A Human Rights, Environmental and Economic Monstrosity. Climate Justice Programme, Friends of the Earth International. https://www.foe.co.uk/sites/default/files/downloads/gas_flaring_nigeria.pdf

CEIC Nigeria Gross National Product (2018). https://www.ceicdata.com/en/indicator/nigeria/gross-national-product

Declan, H. (2016). What Gas Flaring Provision Bill Will Achieve. The Punch. http://punchng.com/gas-flaring-prohibition-bill-will-achieve

Etikerentse, G. (2004). Nigerian Petroleum Law (2nd ed., p. 148). Lagos: Dredew Publishers.

IUCN/UNEP/WWF (1980). World Conservation Strategy: Living Source Conservation for Sustainable Development (Para. 1.4). https://doi.org/10.2305/IUCN.CH.1980.9.en

Mba, C. H. (2000). Environmental Protection and National Development: Towards Optimal Resolution of Conflicting Measures and Strategies. In A. Akpuru-Aja, \& A. C. Emeribe (Eds.), Policy and Contending Issues in Nigerian National Development Strategy). Enugu: John Jacob's Publishers, Ltd.

McNeely, J. A. et al. (1996). Conserving the World's Biological Diversity (p. 17).

Michiko, I. (2004). Gas Flaring in the Niger Delta: The Potential Benefits of Its Reduction on the Local Economy and Environment. https://pdfs.semanticscholar.org/a29f/69cf8551ccc35fe9d5609a1d82d46ae860fd.pdf?_ga $=2.7536050 .1895606060 .1566574900-1196102768.1566574900$

Ndubuisi, A. L., \& Asia, I. O. (2007). Environmental Pollution in Oil Producing Areas of the Niger Delta Basin, Nigeria: Empirical Assessment of Trends and People's Perception. Environmental Research Journal, 1, 18-26.

http://medwelljournals.com/abstract/?doi=erj.2007.18.26

Niger Delta Environmental Survey (1997). Environmental and Socio-Economic Characteristics, Second Phase of Field Report, 10th July 1997 (Vol. 1). Lagos: Environmental Resource Manager Limited.

Nnimo, B. (2010). The UN Reports on Nigerian Oil Spill Relies Too Heavily on Data from Shell.

http://www.theguardian.com/environment/cif-green/2010/aug/25/un-nigeria-oil-spill-s hell

Nwilo, C. P., \& Badejo, T. O. (2005). Impacts and Management of Oil Spill Pollution along the Nigerian Coastal Areas. Administering Marine Spaces: International Issues $119,2006$.

Okiwelu, S. N., \& Anyawu, D. I. (2003). Dictionary of Ecology, Conservation and Environmental Sciences (p. 16). Lagos: Niyi Faniran Publishers.

Osisanya, S. O. (2003). Environmental Problems Related to Oil Exploration Activities; the Elements of Biodiversity. http://www.biologicaldiversity.org/programs/biodiversity/elements_of_biodiversity

Osuagwu, E. S., \& Olaifa, E. (2018). Effects of Oil Spills on Fish Production in the Niger Delta. PLoS ONE, 13, e0205114. https://doi.org/10.1371/journal.pone.0205114 https://journals.plos.org/plosone/article/figure?id=10.1371/journal.pone.0205114.g003 
Pyagbara, L. S. (2007). The Impact of Bio-Diversity.

https://www.un.org/esa/socdev/unpfii/documents/workshop_IPPE_pyagbara.doc

Soules, M. E. (1991). Conservation: Tactics for a Constant Crisis. Science, 253, 774-750. https://doi.org/10.1126/science.253.5021.744

Sunmoni, M. (2012). Gas Flaring in Nigeria; What Are the Harmful Effects? http://www.ecoremediation.blogspot.com/2012/06/gas-flaring-in-nigeria-what-are-har mful.html

The United Nations Agenda 21-Nigeria (2012). https://sustainabledevelopment.un.org/content/documents/1023nigerianationalreport. pdf

U.S. Energy Information Administration. OPEC Annual Statistical Bulletin 2015. https://www.opec.org/opec_web/static_files_project/media/downloads/publications/AS B2015.pdf

United Nation's Development Programme UNDP Report (2006). Niger Delta Development Human Report (pp. 185-186).

http://hdr.undp.org/sites/default/files/reports/267/hdr06-complete.pdf

United Nations (1992). Convention on Biological Diversity. https://www.cbd.int/doc/legal/cbd-en.pdf

United Nations Environmental Program UNEP (2011). Environmental Assessment of Ogoni Land. http://www.unep.org/nigeria

Uyigue, E., \& Agho, M. (2007). Coping with Climate Change and Environmental Degradation in the Niger Delta of Southern Nigeria. Community Research and Development Centre Nigeria (CREDC).

http://priceofoil.org/content/uploads/2007/06/07.06.11\%20-\%20Climate_Niger_Delta. pdf

Uyigue, E., \& Ogbeibu, A. E. (2007). Climate Change and Poverty: Sustainable Approach in the Niger Delta Region of Nigeria.

https://www.researchgate.net/publication/242578916_Environmental_Sustainability_a nd_Sustainable_Development_Issues_in_the_Niger_Delta_Region_of_Nigeria/link/02e 7e531be54084550000000/download

Weis, J. (2015). Marine Pollution: What Everyone Needs to Know. Oxford: Oxford University Press.

Wild, A. (1996). Soil and the Environment: An Introduction (pp. 189-210). London: Cambridge University Press. 